\title{
Targeting of alteration for prospecting of polymetal mineralization using remote sensing in Qarah Gol area, Meshgin Shahr, Ardabil province
}

\author{
Shadi ZIA ${ }^{1}$,SEYEDEH NARGES SADATI ${ }^{2 *}$, GHOLAMREZA \\ AHMADZADEH $^{3}$ \\ 1,2,3 Department of Geology, Faculty Science, University of Mohaghegh Ardabili, Ardabil, \\ Iran (*correspondence: sadati_sn@uma.ac.ir)
}

\begin{abstract}
The Qarah Gol area is located in Ahar-Arasbaran zone, $50 \mathrm{~km}$ of Meshgin Shahr, Iran. Geologically most of the area is covered by Eocene rocks, consisting of andesite to basalt, which form a major part of the rock outcrops of the area as lava with pyroclastic rocks including agglomerate, breccia and tuff with andesitic composition. The main image analysis techniques involved in this study were false color composite (FCC) and band ratios. Different RGB color combinations were examined and the 7-5-1, 5-3-1 and 7-4-2 Landsat ETM images proved to be the best for visual interpretation. Color composite ratio images are produced by combining three ratio images in blue, green, and red. Fig.1 shows ratios 5/7, 4/3, $3 / 1$ in red, green, and blue, respectively. In this image the argillic alteration zone is seen as pink color and iron oxides is seen as blue color (this leads to a better discrimination between hydrothermally altered and unaltered rocks in the present area). Hydrothermal alteration involving chlorite, sericite, epidote, carbonate, silica and clay minerals are common. However phyllic, argillic and oxide iron alteration is more common in the area and is suitable for prospecting of polymetal mineralization.
\end{abstract}

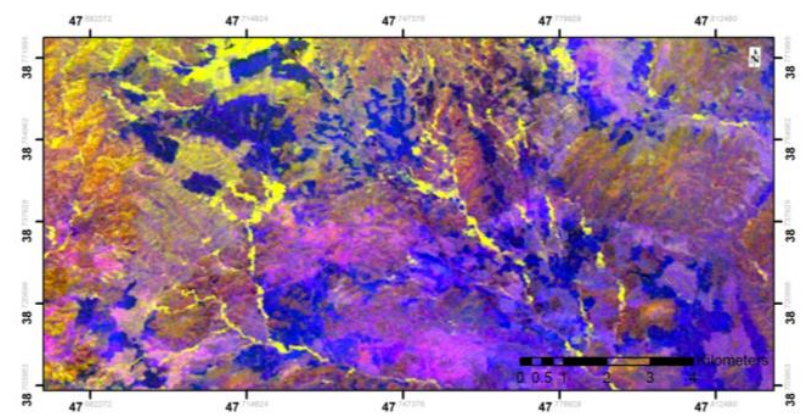

Fig. 6. Landsat ETM+ ratio image (bands 5/7, 4/3, 3/1 in RGB).

\section{Refrences:}

[1] Chen, X., Warner, T. A. and Campagna, D. (2007).

Remote Sensing of Environment, 110, 344-356. 